\title{
Causes of Discrepancies between Design and Construction in the Pakistan Construction Industry
}

\author{
"Rafiq Muhammad Choudhry', Hamza Farooq Gabriel2, \\ Mustafa Kamal Khan ${ }^{3}$ and Salman Azhar ${ }^{4}$
}

Published online: 15 January 2018

To cite this article: Rafiq Muhammad Choudhry, Hamza Farooq Gabriel, Mustafa Kamal Khan and Salman Azhar. (2017). Causes of discrepancies between design and construction in the Pakistan construction industry. Journal of Construction in Developing Countries, 22(2): 1-18. https://doi.org/10.21315/jcdc2017.22.2.1

To link to this article: https://doi.org/10.21315/jcdc2017.22.2.1

\begin{abstract}
In building construction, discrepancies frequently occur between design and construction in relation to architectural details, structural details, materials, and quality of construction. The objective of this paper is to identify the major causes of discrepancies in building construction. A questionnaire was utilised that contained 65 potential causes of discrepancies classified into 4 categories: design, tendering, construction, and overall project. The data was from Pakistan and the response rate was excellent (80.6\%). The collected data was analysed and important causes of discrepancies were identified. The results indicate that the provision of incomplete data to designers, lack of interest by approving authorities to carefully check the design, and owner-proposed changes due to financial problems are the top three causes of discrepancies. Insights and discussion are included in the paper. This work provides a basis to minimise discrepancies in the construction industry and help reduce rework, delays, and defects in construction.
\end{abstract}

Keywords: Building construction, Design errors, Construction discrepancies, Relative importance index

\section{INTRODUCTION}

Construction and engineering practitioners have found it increasingly difficult to learn from their mistakes, particularly regarding design errors and discrepancies (Lopez et al., 2010). Evidence of this is contained in reports of "high profile" errors and discrepancies that have contributed to the failure of buildings and engineering infrastructure (e.g., Hauck, 1983). Design discrepancies continue to be a major contributor to building and engineering infrastructure failures and project time and cost overruns (Sun and Meng, 2009; Love et al., 2009). Han, Love and Pena-Mora (2013) contend that design errors and discrepancies leading to rework and/or design changes are the primary contributor to schedule delays and cost overruns in design and construction projects. Non-value-added effort (NVAE) from errors and changes in design and construction are identified by Han, Lee and PeñaMora (2012). They show that NVAE or wasted effort can be avoided if the project is carefully planned and executed. Discrepancies and changes can have harmful

\footnotetext{
'Department of Civil Engineering, College of Engineering, Al Imam Mohammad Ibn Saud Islamic University, Riyadh, SAUDI ARABIA

${ }^{2}$ School of Civil and Environmental Engineering, National University of Sciences and Technology, Islamabad, PAKISTAN

${ }^{3}$ Capital Development Authority, Islamabad, PAKISTAN

${ }^{4} \mathrm{McWhorter}$ School of Building Science, Auburn University, Alabama, USA

"Corresponding email: choudhry03@gmail.com
} 
effects on performance, most often producing a ripple effect among the activities needed to complete a project (Lee, Peña-Mora and Park, 2006a). Discrepancies, errors, and changes in one activity can easily propagate to other activities due to physical and procedural relationships (Lee, Peña-Mora and Park, 2006b). Lopez and Love (2012) state that design errors and discrepancies can adversely influence project performance and contribute to failures, accidents, and loss of life. Wang et al. (2016) show that design management is critical to project performance. Andi and Minato (2003) state that defective design has an adverse impact on project performance and that this issue needs to be carefully addressed.

Every building construction project begins with the objective of completing the project in accordance with the details of the contract. The client, the consultant, and the contractor contribute their share to fulfil the requirements at the start of a project. When a project progresses into the construction phase, the requirements and quality standards defined during the design phase start to change (Alarcón and Mardones, 1998). The problem is that although a discrepancy in design and construction may be small, it is usually significant. In building construction, discrepancies occur in various phases, for example, the design phase and the construction phase. These discrepancies may include changes in the size of rooms, false ceiling heights, locations and thicknesses of walls, locations and sizes of doors and windows, locations of underground and overhead water tanks, plinth levels from the ground surface, locations of beams and columns, sizes of beams, foundation types and sizes, reinforcement details, quality of concrete, changes in bricks and tiles, changes in paints and finishes, quality of workmanship, insulating materials, changes in plumbing pipes and accessories, and changes in electric cables and accessories.

Pakistan is a developing country that has experienced rapid expansion in construction activities with economic growth of 4.24\% in 2014-2015 (Ministry of Finance, 2015). According to the Ministry of Finance (2015), construction represents $12 \%$ of industrial components and grew at $7.05 \%$ in 2014-2015. Large and complex projects, such as the China-Pakistan economic corridor (CPEC), are being built and can lead to inadequate designs resulting in changes to plans, specifications, and contracts. Large and complex building projects are being built due to demands from both the public and private sectors. A chief executive officer (CEO) of a consulting company revealed that design firms omit design audits, reviews, and verifications to maximise their fees and profits. Discrepancies, errors, and defects can occur during the design and construction stages due to these omissions. To detect incompatibilities and increase the service life of projects, it is essential that important causes of errors and discrepancies are identified and eliminated or reduced. This research study was conducted with the following objectives:

1. Identify causes of discrepancies between design and construction of building projects and investigate their relative importance;

2. Rank the causes to determine differences in the perception of clients, consultants and contractors; and

3. Investigate agreement on the categories of discrepancies between clients, consultants, and contractors. 
This research is carried out to gain insight into the causes of discrepancies and errors in design and construction in the building industry, a topic that has been largely ignored by researchers. This work is important because it provides the viewpoints of the three key stakeholders: the client, the consultant, and the contractor. The study is focused on traditional design-bid-build construction.

\section{LITERATURE REVIEW}

Every individual makes errors. Technical errors occur when a person fails to correctly carry out a procedure (Wantanakorn, Mawdesley and Askew, 1999) and are relatively easy to identify. For example, if someone added 3 and 4 and arrived at an answer of 6.5, this would be easily identified as an error and corrected. Design discrepancies and changes are more complicated and diverse. According to Mohamad, Nekooie and Al-Harthy (2012), design changes are common in building projects. Any change in the design or construction of a project after the contract is awarded and signed is defined as a design change. Variations and changes occur in all types of construction projects (Thomas et al., 2002). Even if thoroughly planned, changes are still inevitable in the contract as work progresses (Al-Hammad, 2000). These changes in the design phase and ultimately in the construction phase create problems between the contracting parties.

Mendelsohn (1997) found that $75 \%$ of the problems faced on site are caused at the design phase. Many design defects are detected during the execution phase of project that may lead to rework (Oyewobi et al., 2011). Mohammed et al. (2010) postulate that changes in the plans by the owner, substitutions of material by the owner or the contractor, and changes in the design by the consultant are the main causes of variations in building projects in Selangor, Malaysia. Grau, Back and Prince (2012) reveal that conflicts between designers and contractors are attributable to poor design planning, inaccuracy of design documents, high build cost of design options, delay of drawings, and unreasonable design fees. Tribelsky and Sacks (2010) measured the flow of information in the process of detailed design where construction documents are prepared. Tenah (2001) notes that what appears good on drawings or on the computer screen is sometimes difficult to build, and designers seek modifications in the plans during the construction stage. These discrepancies result in rework, changes in quantities, and delays and defects in construction. Kong and Gray (2006) indicate that the most prominent source of delays and consequent disputes on construction projects in Malaysia was disagreement between the contracting parties. Variations and delays result in reduced investment that generally reduces the overall growth of building construction and sometimes leads to unemployment.

Wang (2000) reveals that conflicts between the stakeholders were frequent in projects marked by poor management. These can include approvals, reporting procedures, and inspections. Mohamad, Nekooie and Al-Harthy (2012) indicate that almost all projects undergo various changes, not only at the design stage but also during construction. Discrepancies in design and construction may result in delays in project duration, compromises in quality, or increase in cost. Eliminating discrepancies enable the project management team to complete the project successfully (Arain, Pheng and Assaf, 2006). It is important to evaluate the potential causes of discrepancies during the project life-cycle. 


\section{RESEARCH METHOD}

This section describes the research method, questionnaire development and data collection. A questionnaire was designed and subsequently modified to evaluate the importance of identified causes. Literature review provided the foundation for developing the questionnaire used as the research instrument. The data was collected by distributing the questionnaire to clients, consultants, and contractors. Responses to the questionnaire were then analysed. The client is the owner or employer of the project. The contractor is the constructor or builder of the project with whom the owner entered into a construction contract. The consultant is the designer or engineer of the project with whom the owner entered into a professional services contract.

\section{Questionnaire}

Guidance for designing the questionnaire was obtained from the literature review. The questionnaire consists of 65 causes of discrepancies grouped into 3 categories. The researchers performed a pilot test with two clients, six consultants, and seven contractors and then conducted interviews with each participant. Every respondent had more than 10 years of experience in the building construction industry. The questionnaire was modified based on feedback from these experts. The researchers created a cover letter and survey instructions for participants to give them assurance that their responses would be anonymous. The final questionnaire solicited information about respondents covering their qualifications, designation, working experience in building construction, and the category they represent: clients, consultants or contractors. The questionnaire contained four sections covering the design phase, tendering phase, construction phase, and overall project. In the design phase, 20 incompatibility causes were listed; 5 from Arain, Pheng and Assaf (2006) and the rest from the input of the experts from the pilot study. The tendering phase was a new addition comprising seven causes. In the construction phase, 24 causes were identified; 6 from Arain. Pheng and Assaf (2006) and the rest from the input of the experts. In the overall project section, 14 causes were identified; 8 from Arain, Pheng and Assaf (2006) and the rest from the input of the experts. Of the 65 items, 19 were adopted from Arain, Pheng and Assaf (2006). The questionnaire used a 5-point Likert-type scale (5 = extremely important, 4 = very important, 3 = moderately important, $2=$ slightly important, and $1=$ not important) to facilitate statistical analysis of the responses.

\section{Sample}

Surveys were administered to clients, consultants, and contractors. There are 41,025 consultants, clients, and contractors registered with the Pakistan Engineering Council (Pakistan Engineering Council, 2014). The sample size that represents the target population is determined from an equation that is widely used by researchers (Arain and Pheng, 2005; Kish, 1995):

$$
n=\frac{n^{\prime}}{1+n^{\prime} / N}
$$


where,

$\mathrm{n}^{\prime}=$ sample size from infinite population $=\mathrm{S}^{2} / \mathrm{V}^{2}$

$\mathrm{n}$ = sample size from finite population

$\mathrm{N}=$ total population $(41,025)$

$V=$ standard error of sample population equal to 0.05 for the confidence interval $95 \%$

$S^{2}=$ standard error variance of population

$\mathrm{S}^{2}=\mathrm{P}(1-\mathrm{P})$; maximum $\mathrm{P}=0.5$.

The sample size for the target population was calculated as follows:

$$
\begin{aligned}
& n^{\prime}=S^{2} / V^{2} \\
& n^{\prime}=(0.5)^{2} /(0.05)^{2}=100 \\
& n=100 /(1+100 / 41,025)=100
\end{aligned}
$$

In total, 165 hard-copy questionnaires were distributed with a response rate of $80.6 \%$, resulting in 135 questionnaires collected. Respondents included 19 clients, 75 consultants, and 41 contractors. Two incomplete questionnaires were discarded. These discarded surveys were considered invalid since their use would distort the results. The sample was reduced to 133 for data analysis. Of the 133 respondents (8 clients, 33 consultants, and 15 contractors), $42 \%$ had building project experience of 0 to 10 years, $32 \%$ had experience of 11 to 20 years, $15 \%$ had experience of 21 to 30 years, and the remaining $11 \%$ had more than 30 years of experience (see Figure 1). Considering education, $48 \%$ of the respondents had engineering degrees, $24 \%$ had earned technical certificates (diplomas), $18 \%$ had non-engineering bachelor's degrees, and the remaining $10 \%$ had secondary education.

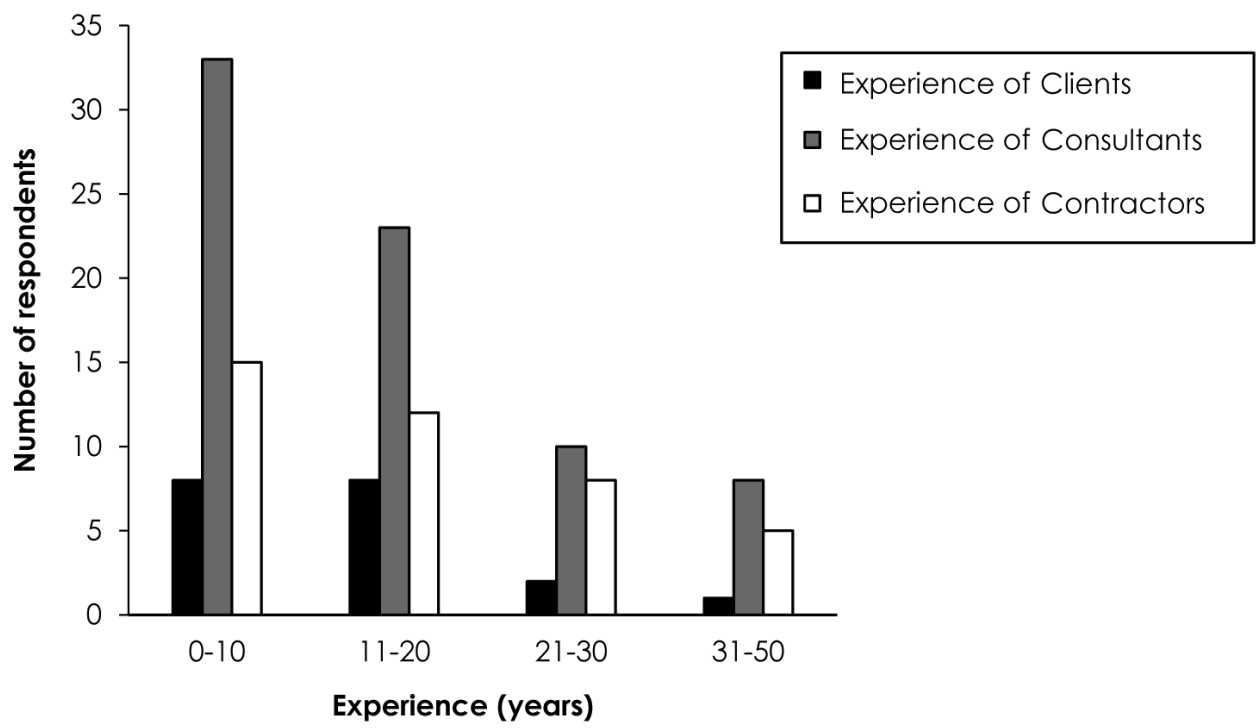

Figure 1. Experience of the Respondents 


\section{Reliability Analysis}

Reliability of the collected data was assessed using a statistical package for social sciences (SPSS) version 19.0. A reliability test was conducted to check whether each item in the scale was free from error of measurement (Leech, Barrett and Morgan, 2005). If a questionnaire is examined at different times and across different populations, and it produces the same results, the questionnaire is "reliable" (Hinton et al., 2004). In this test, Cronbach's alpha values ranged from 0 (un-reliable) to 1 (reliable) with 0.75 being considered a relatively strong value of reliability. In SPSS, widely used methods for assessing reliability are Cohen's Kappa Coefficient for categorical data and Cronbach's alpha for continuous data (Likert-type scales). Since the data were based on a Likert-scale, Cronbach's alpha method was used to check reliability.

\section{Relative Importance Index}

A relative importance index (RII) was computed for each cause, and the causes were ranked for clients, consultants, and contractors. Chan and Kumaraswamy (1997) used Rll to decide the relative importance of attributes. Respondent input on the five-point scale in the questionnaire was transformed to a relative importance index for each cause to determine the rank of that cause for each stakeholder. The formula for the RII (Chan and Kumaraswamy, 1997) is:

$$
R \|=\sum W /(A \times N)
$$

where,

$w=$ weighting as assigned by each respondent in a range from 1 to 5 , where implies not important, 5 implies extremely important)

$A=$ the highest weight, e.g., "5"

$\mathrm{N}=$ the total responses in the sample.

\section{Rank Agreement Factors}

The rank agreement factors (RAF) are calculated using the formula and method described by Okpala and Aniekwu (1988) and used by several researchers, including Chan and Kumaraswamy (1997), to quantify the agreement in ranking between groups: client, consultant, and contractor. The RAF varies from 0 , indicating perfect agreement, to a higher value indicating increased disagreement. The researchers calculated the percentage disagreement (PD) and percentage agreement (PA). The RAF, PD, and PA for all groups of respondents, as described by Chan and Kumaraswamy (1997), are listed below:

Absolute Difference $(\mathrm{Di})=\left|\mathrm{Ri}_{1}-\mathrm{Ri}_{2}\right|$

Eq. 4 where $\mathrm{Ri}_{1}=$ ranking of First Group, $\mathrm{Ri}_{2}=$ ranking of Second Group.

Maximum Absolute Difference $\left(D_{\max }=\left|\mathrm{Ri}_{1}-\mathrm{Rj}_{2}\right|\right.$

where $\mathrm{Ri}_{1}=$ ranking, $\mathrm{Rj}_{2}=$ ranking with absolute maximum difference. 
Rank Agreement Factor (RAF) $=\sum D / N$

Eq. 5

where $\mathrm{D}=$ absolute difference, $\mathrm{N}=$ number of categories, $\mathrm{j}=\mathrm{N}-\mathrm{i}+\mathrm{l}$

Percentage Disagreement $(\mathrm{PD})=\mathrm{RAF} / \mathrm{RAF}_{\max }$ or $(\mathrm{Di} / \mathrm{N}) /\left(\mathrm{D}_{\max } / \mathrm{N}\right)$

Percentage Agreement $(P A)=100 \%-P D$

\section{ANALYSIS AND RESULTS}

This section provides the results of the reliability analysis, RII, RAF, and PA. The reliability results are given in Table 1. The results indicate that Cronbach's alpha values for respondents are above 0.75; thus, all the causes in each category are retained.

Table 1. Cronbach's Alpha of Categories of Incompatibilities

\begin{tabular}{lccc}
\hline Category & Client & Consultant & Contractor \\
\hline Design phase & 0.922 & 0.903 & 0.933 \\
Tendering phase & 0.862 & 0.756 & 0.870 \\
Construction phase & 0.938 & 0.929 & 0.970 \\
Overall project phase & 0.941 & 0.904 & 0.957 \\
\hline
\end{tabular}

Using the Rll, the causes and the categories of causes are ranked from the perspective of the clients, the consultants, and the contractors. The ranking of causes and categories are discussed in the following sections.

\section{Design Phase}

The design phase category contains 20 causes. The Rll and ranking for each cause is shown in Table 2. The cause "data provided to designer are incomplete" is ranked in the $1^{\text {st }}$ position within this category $(R \|=0.72)$. Based on the overall ranking of each respondent, this cause was ranked 1st by clients and consultants, and 3rd by contractors. This cause is also ranked in the 1st position of the overall ranking of all phases. "Approving authorities do not check carefully that the structure is designed according to the building bye-laws, codes and government rules" is ranked in the 2nd position in this group (RII = 0.70). It is ranked 10th by clients, 3rd by consultants, and 1st by contractors. This cause is ranked in the 2 nd position in terms of the overall ranking. "Too little time is given to the designer for completion of the design documents" is ranked in the 3rd position in the design phase category $(\mathrm{RII}=0.68)$. It is ranked 7th by clients, 2 nd by consultants, and 14th by contractors. This cause is ranked in the 5th position overall.

\section{Tendering Phase}

The tendering phase contains seven causes. The Rll and ranking for each cause is shown in Table 3. All causes in this category received low rankings ranging from 23rd to 53rd with the RII ranging from 0.60 to 0.47 . The results reveal that clients, consultants, and contractors are successful in addressing these cause factors with no major issues of incompatibility. 
Table 2. Ranking of Causes for Design Phase

\begin{tabular}{|c|c|c|c|c|c|c|c|c|c|}
\hline \multirow{2}{*}{ Cause } & \multicolumn{2}{|c|}{ Client } & \multicolumn{2}{|c|}{ Consultant } & \multicolumn{2}{|c|}{ Contractor } & \multicolumn{2}{|c|}{ Overall } & \multirow{2}{*}{ RC } \\
\hline & RII & Rank & RII & Rank & RII & Rank & RII & Rank & \\
\hline $\begin{array}{l}\text { Contractor is not involved in the } \\
\text { conceptual phase of design. }\end{array}$ & 0.46 & 56 & 0.43 & 61 & 0.52 & 30 & 0.46 & 56 & 20 \\
\hline $\begin{array}{l}\text { Contractor is not involved in the } \\
\text { development phase of design. }\end{array}$ & 0.52 & 47 & 0.45 & 58 & 0.50 & 36 & 0.48 & 51 & 18 \\
\hline $\begin{array}{l}\text { Data provided to designer are } \\
\text { incomplete. }\end{array}$ & 0.75 & 1 & 0.74 & 1 & 0.66 & 3 & 0.72 & 1 & 1 \\
\hline $\begin{array}{l}\text { Data provided to designer is } \\
\text { incorrect. }\end{array}$ & 0.66 & 16 & 0.62 & 22 & 0.45 & 49 & 0.58 & 26 & 9 \\
\hline Data is provided late to designer. & 0.64 & 25 & 0.64 & 17 & 0.57 & 17 & 0.62 & 17 & 7 \\
\hline $\begin{array}{l}\text { Lack of human resources with } \\
\text { designer. }\end{array}$ & 0.69 & 10 & 0.65 & 14 & 0.60 & 6 & 0.64 & 12 & 6 \\
\hline $\begin{array}{l}\text { Designer busy in too many } \\
\text { assignments. }\end{array}$ & 0.62 & 29 & 0.59 & 28 & 0.49 & 43 & 0.56 & 29 & 10 \\
\hline $\begin{array}{l}\text { Designer's knowledge is lacking } \\
\text { in building bye-laws, codes and } \\
\text { government rules. }\end{array}$ & 0.56 & 41 & 0.58 & 30 & 0.40 & 62 & 0.52 & 43 & 14 \\
\hline $\begin{array}{l}\text { Designer's knowledge is lacking in } \\
\text { constructability of design. }\end{array}$ & 0.43 & 61 & 0.54 & 43 & 0.52 & 28 & 0.52 & 44 & 15 \\
\hline $\begin{array}{l}\text { Designer's knowledge is lacking } \\
\text { on availability of materials. }\end{array}$ & 0.60 & 34 & 0.57 & 34 & 0.52 & 30 & 0.56 & 32 & 11 \\
\hline $\begin{array}{l}\text { Designer's knowledge is lacking } \\
\text { on engineering design technique } \\
\text { and software. }\end{array}$ & 0.54 & 44 & 0.51 & 45 & 0.43 & 55 & 0.49 & 48 & 17 \\
\hline $\begin{array}{l}\text { Lack of designer's knowledge } \\
\text { concerning engineering drafting. }\end{array}$ & 0.49 & 51 & 0.51 & 47 & 0.47 & 46 & 0.49 & 46 & 16 \\
\hline $\begin{array}{l}\text { Lack of designer's knowledge for } \\
\text { suitability of materials. }\end{array}$ & 0.60 & 34 & 0.55 & 41 & 0.51 & 34 & 0.54 & 39 & 13 \\
\hline $\begin{array}{l}\text { Frequent replacement of } \\
\text { designer by the owner. }\end{array}$ & 0.56 & 41 & 0.58 & 30 & 0.51 & 34 & 0.55 & 34 & 12 \\
\hline $\begin{array}{l}\text { Personal and social problems } \\
\text { of designer. }\end{array}$ & 0.47 & 55 & 0.48 & 51 & 0.47 & 46 & 0.48 & 51 & 19 \\
\hline $\begin{array}{l}\text { Lack of reward, delayed } \\
\text { payment or less payment to } \\
\text { designer by owner. }\end{array}$ & 0.72 & 3 & 0.67 & 13 & 0.58 & 14 & 0.65 & 10 & 5 \\
\hline $\begin{array}{l}\text { Too little time is given to designer } \\
\text { for completion of the design } \\
\text { documents. }\end{array}$ & 0.71 & 7 & 0.73 & 2 & 0.58 & 14 & 0.68 & 5 & 3 \\
\hline $\begin{array}{l}\text { Lack of project planning and } \\
\text { analysis by owner at the project } \\
\text { start. }\end{array}$ & 0.73 & 2 & 0.67 & 10 & 0.60 & 6 & 0.66 & 8 & 4 \\
\hline
\end{tabular}


Table 2. (continued)

\begin{tabular}{|c|c|c|c|c|c|c|c|c|c|}
\hline \multirow{2}{*}{ Cause } & \multicolumn{2}{|c|}{ Client } & \multicolumn{2}{|c|}{ Consultant } & \multicolumn{2}{|c|}{ Contractor } & \multicolumn{2}{|c|}{ Overall } & \multirow{2}{*}{ RC } \\
\hline & RII & Rank & RII & Rank & RII & Rank & RII & Rank & \\
\hline $\begin{array}{l}\text { Frequent changes in the design } \\
\text { due to owner dis-satisfaction. }\end{array}$ & 0.72 & 3 & 0.65 & 14 & 0.50 & 38 & 0.62 & 18 & 8 \\
\hline $\begin{array}{l}\text { Approving authorities do not } \\
\text { check carefully that the structure } \\
\text { is designed according to the } \\
\text { building bye-laws, codes and } \\
\text { government rules. }\end{array}$ & 0.69 & 10 & 0.72 & 3 & 0.69 & 1 & 0.70 & 2 & 2 \\
\hline
\end{tabular}

Note: $\mathrm{RC}=$ Rank within this category

Table 3. Ranking of Causes for Tendering Phase

\begin{tabular}{|c|c|c|c|c|c|c|c|c|c|}
\hline \multirow{2}{*}{ Cause } & \multicolumn{2}{|c|}{ Client } & \multicolumn{2}{|c|}{ Consultant } & \multicolumn{2}{|c|}{ Contractor } & \multicolumn{2}{|c|}{ Overall } & \multirow{2}{*}{$\mathrm{RC}$} \\
\hline & RII & Rank & RII & Rank & RII & Rank & RII & Rank & \\
\hline $\begin{array}{l}\text { Incomplete or inaccurate design } \\
\text { documents un-intentionally } \\
\text { provided with bidding documents. }\end{array}$ & 0.59 & 38 & 0.46 & 55 & 0.45 & 49 & 0.47 & 53 & 7 \\
\hline $\begin{array}{l}\text { Incomplete or inaccurate design } \\
\text { documents intentionally provided } \\
\text { with bidding documents. }\end{array}$ & 0.61 & 32 & 0.56 & 37 & 0.50 & 38 & 0.55 & 36 & 5 \\
\hline $\begin{array}{l}\text { Type of construction contract in } \\
\text { use. }\end{array}$ & 0.59 & 38 & 0.50 & 49 & 0.39 & 63 & 0.48 & 50 & 6 \\
\hline $\begin{array}{l}\text { Contractor did not consider that } \\
\text { the design is exotic, complex or } \\
\text { difficult to build, and he does not } \\
\text { have the required expertise. }\end{array}$ & 0.60 & 34 & 0.60 & 27 & 0.52 & 30 & 0.57 & 27 & 2 \\
\hline $\begin{array}{l}\text { Selection of contractor on the } \\
\text { basis of lowest bid. }\end{array}$ & 0.51 & 48 & 0.62 & 24 & 0.61 & 5 & 0.60 & 23 & 1 \\
\hline $\begin{array}{l}\text { Amount of performance security } \\
\text { and retention money. }\end{array}$ & 0.62 & 29 & 0.58 & 29 & 0.51 & 33 & 0.57 & 28 & 3 \\
\hline $\begin{array}{l}\text { Absence of third-party validation } \\
\text { during defect liability period. }\end{array}$ & 0.56 & 41 & 0.58 & 32 & 0.53 & 26 & 0.56 & 31 & 4 \\
\hline
\end{tabular}

Note: $\mathrm{RC}=$ Rank within this category

\section{Construction Phase}

The construction phase category contains 24 causes. The Rll and ranking for each cause are shown in Table 4. For this category, "owner proposes changes due to financial problems" is ranked in the 1st position ( $R \|=0.69)$. This cause factor is ranked 10th by clients, 9th by consultants, and 2nd by contractors. It is ranked in the 3rd position in terms of the overall ranking of all phases. "Approving authorities do not check carefully that the structure is constructed according to the approved building plans" is ranked in the 2 nd position in this category ( $R I I=0.68)$. This cause factor is 
ranked 3rd by clients, 6th by consultants, and 4th by contractors. It is ranked in the 4th position in the overall ranking. "Contractor's lack skilled manpower" is ranked in the 3rd position in this category (RII $=0.67$ ). This cause factor is ranked 14 th by clients, 4th by consultants, and 12th by contractors. This cause is ranked in the 6th position in the overall ranking.

Table 4. Ranking of Causes for Construction Phase

\begin{tabular}{|c|c|c|c|c|c|c|c|c|c|}
\hline \multirow{2}{*}{ Cause } & \multicolumn{2}{|c|}{ Client } & \multicolumn{2}{|c|}{ Consultant } & \multicolumn{2}{|c|}{ Contractor } & \multicolumn{2}{|c|}{ Overall } & \multirow{2}{*}{ RC } \\
\hline & RII & Rank & RII & Rank & RII & Rank & RII & Rank & \\
\hline $\begin{array}{l}\text { Owner proposes changes because } \\
\text { he had planned to make changes } \\
\text { during construction. }\end{array}$ & 0.44 & 59 & 0.57 & 33 & 0.60 & 6 & 0.56 & 29 & 13 \\
\hline $\begin{array}{l}\text { Owner proposes changes during } \\
\text { construction due to sudden } \\
\text { changes in his requirements/ } \\
\text { expectations. }\end{array}$ & 0.45 & 57 & 0.56 & 37 & 0.48 & 45 & 0.52 & 42 & 18 \\
\hline $\begin{array}{l}\text { Owner proposes changes during } \\
\text { construction due to change in } \\
\text { ownership. }\end{array}$ & 0.40 & 62 & 0.44 & 60 & 0.56 & 20 & 0.47 & 54 & 20 \\
\hline $\begin{array}{l}\text { Owner proposes changes to assert } \\
\text { his authority and make undue } \\
\text { interference in construction. }\end{array}$ & 0.26 & 65 & 0.38 & 64 & 0.50 & 36 & 0.40 & 64 & 24 \\
\hline $\begin{array}{l}\text { Owner proposes changes due to } \\
\text { financial problems. }\end{array}$ & 0.69 & 10 & 0.68 & 9 & 0.69 & 2 & 0.69 & 3 & 1 \\
\hline $\begin{array}{l}\text { Slowness in decision making } \\
\text { process by owner. }\end{array}$ & 0.64 & 25 & 0.69 & 7 & 0.53 & 26 & 0.63 & 13 & 5 \\
\hline $\begin{array}{l}\text { Changes in building codes, bye- } \\
\text { laws and government rules. }\end{array}$ & 0.48 & 53 & 0.47 & 54 & 0.41 & 59 & 0.45 & 59 & 23 \\
\hline $\begin{array}{l}\text { Delayed revision of drawings by } \\
\text { designer. }\end{array}$ & 0.69 & 10 & 0.62 & 23 & 0.56 & 19 & 0.61 & 20 & 9 \\
\hline $\begin{array}{l}\text { Drawings not properly stamped or } \\
\text { certified by designer. }\end{array}$ & 0.51 & 48 & 0.45 & 56 & 0.45 & 49 & 0.46 & 56 & 22 \\
\hline $\begin{array}{l}\text { Custody and supply of drawings } \\
\text { at site. }\end{array}$ & 0.45 & 57 & 0.48 & 52 & 0.45 & 52 & 0.46 & 55 & 21 \\
\hline $\begin{array}{l}\text { Delayed approval of drawings by } \\
\text { owner or consultant. }\end{array}$ & 0.67 & 15 & 0.55 & 42 & 0.49 & 40 & 0.55 & 38 & 15 \\
\hline $\begin{array}{l}\text { Material changes due to shortage } \\
\text { of particular material in the market. }\end{array}$ & 0.66 & 16 & 0.63 & 21 & 0.59 & 12 & 0.62 & 16 & 8 \\
\hline $\begin{array}{l}\text { Material changes due to } \\
\text { procurement delays by contractor. }\end{array}$ & 0.66 & 16 & 0.63 & 20 & 0.56 & 20 & 0.61 & 21 & 10 \\
\hline $\begin{array}{l}\text { Contractor does not follow } \\
\text { recommended construction } \\
\text { methods and reluctant to use } \\
\text { proper construction equipment. }\end{array}$ & 0.65 & 21 & 0.69 & 8 & 0.49 & 40 & 0.62 & 15 & 7 \\
\hline
\end{tabular}


Table 4. (continued)

\begin{tabular}{|c|c|c|c|c|c|c|c|c|c|}
\hline \multirow{2}{*}{ Cause } & \multicolumn{2}{|c|}{ Client } & \multicolumn{2}{|c|}{ Consultant } & \multicolumn{2}{|c|}{ Contractor } & \multicolumn{2}{|c|}{ Overall } & \multirow{2}{*}{$\mathrm{RC}$} \\
\hline & RII & Rank & RII & Rank & RII & Rank & RII & Rank & \\
\hline $\begin{array}{l}\text { Contractor lacks in skilled } \\
\text { manpower. }\end{array}$ & 0.68 & 14 & 0.72 & 4 & 0.59 & 12 & 0.67 & 6 & 3 \\
\hline $\begin{array}{l}\text { Contractor lacks in comprehension } \\
\text { of drawing details. }\end{array}$ & 0.71 & 7 & 0.70 & 5 & 0.60 & 10 & 0.67 & 7 & 4 \\
\hline $\begin{array}{l}\text { Contractor lacks in coordination } \\
\text { and management during } \\
\text { construction. }\end{array}$ & 0.66 & 16 & 0.56 & 40 & 0.40 & 61 & 0.53 & 41 & 17 \\
\hline $\begin{array}{l}\text { Contractor's staff facing shortage } \\
\text { of tools and/or equipment for } \\
\text { measurement, alignment and/or for } \\
\text { adjustment at corners. }\end{array}$ & 0.65 & 21 & 0.65 & 16 & 0.58 & 14 & 0.63 & 14 & 6 \\
\hline $\begin{array}{l}\text { Contractor and his staff focusing on } \\
\text { other projects. }\end{array}$ & 0.64 & 25 & 0.57 & 34 & 0.47 & 46 & 0.55 & 36 & 14 \\
\hline $\begin{array}{l}\text { Lack of awareness of the designer } \\
\text { about the ongoing construction } \\
\text { process. }\end{array}$ & 0.61 & 32 & 0.64 & 18 & 0.55 & 22 & 0.61 & 22 & 11 \\
\hline Unanticipated weather conditions. & 0.51 & 48 & 0.51 & 45 & 0.44 & 54 & 0.49 & 49 & 19 \\
\hline $\begin{array}{l}\text { Unforeseen problems and differing } \\
\text { site conditions. }\end{array}$ & 0.63 & 28 & 0.61 & 26 & 0.54 & 23 & 0.59 & 24 & 12 \\
\hline $\begin{array}{l}\text { Timing of proposed changes, i.e., } \\
\text { whether at the start or at the end } \\
\text { of construction. }\end{array}$ & 0.62 & 29 & 0.52 & 44 & 0.54 & 24 & 0.54 & 40 & 16 \\
\hline $\begin{array}{l}\text { Approving authorities do not } \\
\text { check carefully that the structure } \\
\text { is constructed according to the } \\
\text { approved building plans. }\end{array}$ & 0.72 & 3 & 0.69 & 6 & 0.65 & 4 & 0.68 & 4 & 2 \\
\hline
\end{tabular}

Note: $\mathrm{RC}=$ Rank within this category

\section{Overall Project Phase}

The overall project phase category contains 14 causes. All causes in this category received low rankings, ranging from 9th to 65th with the RIl ranging from 0.66 to 0.37 . The results reveal that clients, consultants, and contractors have adequately addressed these concerns, so they are not a source of major discrepancies.

The design phase is ranked in the 1st position among the overall categories $(R \|=0.58)$, which emphasises the importance of this category. It is ranked lst by clients and consultants, and 2 nd by contractors. The construction phase is ranked in the 2 nd position $(R \|=0.57)$. This category is ranked 2 nd by clients and consultants, and 1 st by contractors. The tendering phase is ranked in the 3rd position (RII = 0.54). This category is ranked 3rd by clients, consultants, and contractors. The overall project phase is ranked 4 th $(R \|=0.51)$. This category is ranked 4 th by clients, consultants, and contractors. The RII and ranking of the categories are listed in Table 5. 
Table 5. Ranking of Categories of Incompatibilities

\begin{tabular}{|c|c|c|c|c|c|c|c|c|}
\hline \multirow{2}{*}{ Category } & \multicolumn{2}{|c|}{ Client } & \multicolumn{2}{|c|}{ Consultant } & \multicolumn{2}{|c|}{ Contractor } & \multicolumn{2}{|c|}{ Overall } \\
\hline & RII & Rank & RII & Rank & RII & Rank & RII & Rank \\
\hline Design phase & 0.608 & 1 & 0.595 & 1 & 0.526 & 2 & 0.576 & 1 \\
\hline Tendering phase & 0.582 & 3 & 0.556 & 3 & 0.499 & 3 & 0.543 & 3 \\
\hline Construction phase & 0.588 & 2 & 0.584 & 2 & 0.528 & 1 & 0.567 & 2 \\
\hline Overall project phase & 0.558 & 4 & 0.523 & 4 & 0.476 & 4 & 0.514 & 4 \\
\hline
\end{tabular}

Results for RAF and PA show that clients and consultants have high agreement (100\%) in ranking the categories of discrepancies. The results also indicate that clients and contractors, as well as consultants and contractors, have $75 \%$ agreement in ranking the categories of discrepancies (see Figure 2).

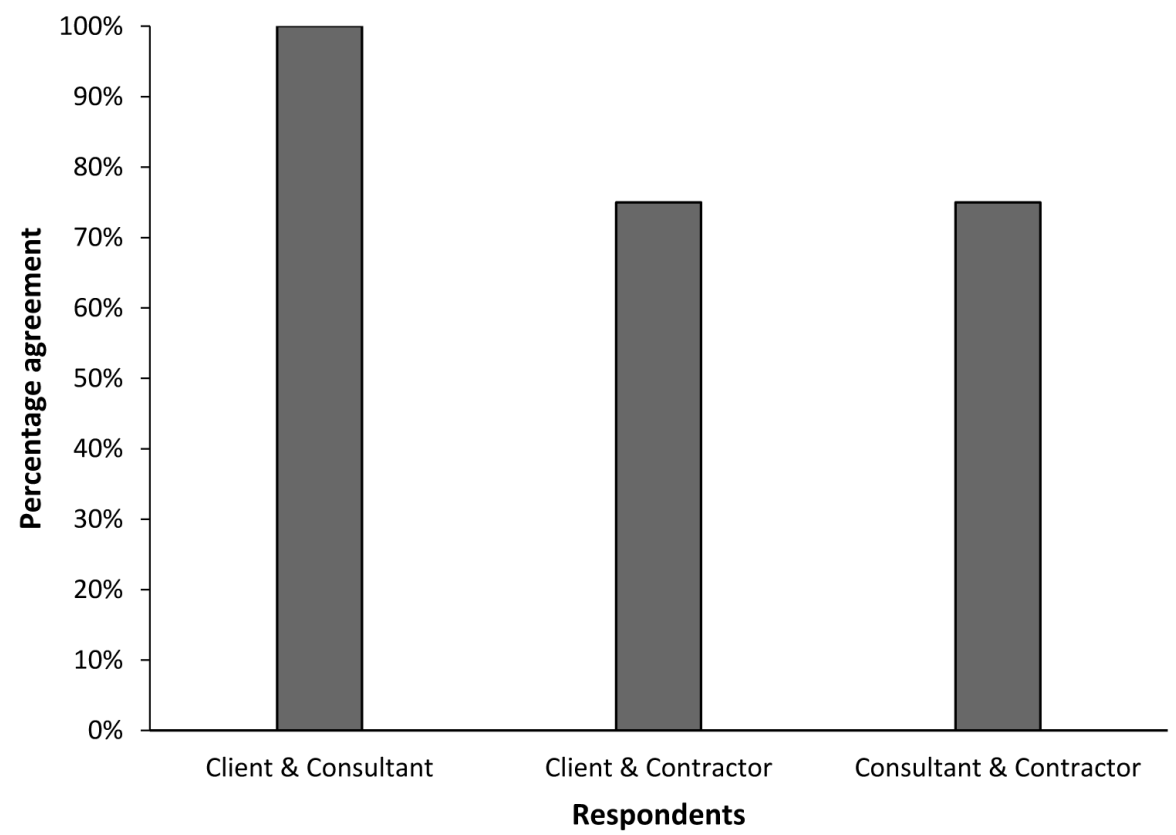

Figure 2. Percentage Agreement between the Respondents

\section{DISCUSSION}

Data analysis and results of this research are presented in previous sections. In this section, we consider their implications for the construction industry. "Data provided to the designer are incomplete" is ranked in the 1st position in overall causes. This factor is ranked 1st by clients and consultants, and 3rd by contractors. The results show that all parties agree concerning the importance of this cause in the creation of discrepancies. The provision of incomplete data to the designer is attributed to 
a deficiency of the organisation on the part of the consultants, as indicated in the interviews. The consultants make unrealistic commitments to the clients regarding the time required for completion of the design documents. Once they realise that the commitment cannot be fulfilled, designers respond by taking shortcuts. They ask the design team to complete the design based on incomplete data. Once construction starts, problems begin to surface due to differences in the design and actual site conditions. Lack of data can result in misinterpretation of the actual requirements of a project (Assaf, Al-Hammad and Al-Shihah, 1996). With insufficient data, designers are compelled to develop designs based on their own perceptions, which may not be what the owner wants.

"Approving authorities do not check carefully that the structure is designed according to the building bye-laws, codes and government rules" is ranked in the 2nd position among overall causes. It is ranked 10th by clients, 3rd by consultants, and 1st by contractors. Consultants and contractors agree that the "not to check the design in accordance to standards" is an important cause of discrepancy for designs. Clients gave this aspect less importance, as they are obligated to enforce building code bye-laws. Interviews indicated that the approving authorities in urban areas and towns are obligated to check the designs of building structures according to the building bye-laws. Periodic checking by the authorities requires project owners and others involved in building construction to follow updated building bye-laws. One interviewee indicated that overseas designers follow the standards of their own countries, which sometimes differ from the local building codes of Pakistan.

"Owner proposes changes due to financial problems" is identified as the 3rd significant cause of incompatibility among the overall causes. This cause is ranked 10th by clients, 9th by consultants, and 2nd by contractors. The results show that contractors find that financial problems of clients are a major source of discrepancies. Clients and consultants give this aspect less importance. For a successful project, the client and consultant need to decide on the exact scope of the project in light of available funds. Interviews revealed that the clients habitually ask for changes when funds and other resources are available. This result is consistent with the findings of other researchers (Arain and Pheng, 2005; Clough, Sears and Sears, 2015). This research concludes that a change in scope of the project by the owner is an important cause for changes when resources (e.g., funds) are available. Al-Hammad (2000) revealed that owners underestimate construction costs of projects but demand higher quality from contractors. Mohamad, Nekooie and Al-Harthy (2012) recognise that owners are a major source of design changes due to modifications to the design, scope changes, and unclear initial design briefs.

"Approving authorities do not check carefully that the structure is constructed according to the approved building plans" is identified as the 4th important cause of discrepancies among the overall causes. It is ranked 3rd by clients, 6th by consultants, and 4th by contractors. The three parties agree that checking the design in construction is an important cause of discrepancies. Approving authorities are obligated to approve project design within their jurisdiction in accordance with the bye-laws that they must enforce. Oversight by the architect or engineer encourages contractors to incorporate additional changes during construction. Mohamad, Nekooie and Al-Harthy (2012) indicated that insufficient details of the existing site condition are a common cause of design changes. They also revealed that contractors tend to use available materials and alternate construction methods to save money. 
"Too little time is given to the designer for completion of the design documents" is ranked as the 5th important factor of discrepancies among the overall causes. It is ranked 7th by clients, 2nd by consultants, and 14th by contractors. Design cannot be developed in a proper manner if too little time is provided, and the designer is forced to complete the design at a lower quality. "Unrealistic design period" is ranked 3rd and 7th by contractors and overall respondents, respectively, as a cause of change orders (Alnuaimi et al., 2010). The results show that clients and consultants agree concerning the level of importance of providing adequate time for the designers to complete the design documents. Contractors give less importance to this cause.

"Contractor lacks skilled manpower" is ranked as the 6th important factor of discrepancies among the overall causes. It is ranked 14th by clients, 4th by consultants, and 12th by contractors. A study conducted by Mohammed et al. (2010) ranked 14th the "contractor lacks in skilled manpower" as the cause of variation in the construction of building projects. The consultants are of the view that this is an important cause of discrepancies.

Of the least important causes identified in this study, "appointment of designer as consultant" is ranked in the 60th position. The appointment of a designer as a consultant may attempt to put the blame for design errors on the contractor. "Withdrawal of licenses and permits" is ranked 61st overall, and "design firm or contractor goes bankrupt and blacklisted" is ranked 62nd. "Appointment of contractor as consultant" is ranked 63rd overall. This result indicates that contractors are rarely appointed as consultants in the construction industry. "Owner proposes changes to assert their authority and make undue interference in construction" is ranked 64th overall. "Nationality of participants" is ranked as the 65th factor of discrepancies among the overall causes. Assaf and Al-Hammad (1988) revealed that overseas designers may not have sufficient knowledge of the local design regulations, and international contractors may not be familiar with the availability of resources, thus, causing design and construction interface problems. Interviews revealed that international companies need to be vigilant about discrepancies or errors in design, construction and other related risks while delivering building construction services. The stakeholders must be aware of the need to improve the integration, planning and control of their designs, and production processes. The owners, consultants, and contractors need to be closely involved to eliminate discrepancies in design and construction.

\section{CONCLUSIONS}

This study identified the causes of discrepancies and errors between the design and construction phases of building projects. The report investigated the relative importance of various factors influencing discrepancies in design and construction. Ranking these causes determined differences in the perceptions of contracting parties, i.e. clients, consultants, and contractors. The results indicate that "data provided to the designer are incomplete" is ranked in the 1st position overall, and this cause is ranked 1st by clients and consultants, and 3rd by contractors. Further results indicate that "approving authorities do not check carefully that the structure is designed according to the building bye-laws, codes and government rules" is ranked in the 2 nd position among overall causes, and it is ranked 10th by clients, 
3rd by consultants, and 1st by contractors. "Owner proposes changes due to financial problems" is identified as the 3rd significant cause of discrepancies, and it is ranked 10th by clients, 9th by consultants, and 2nd by contractors. "Approving authorities do not check carefully that the structure is constructed according to the approved building plans" is identified as the 4th important cause of discrepancies among the overall causes, and it is ranked 3rd by clients, 6th by consultants, and 4th by contractors. "Too little time is given to the designer for completion of the design documents" is ranked as the 5th important factor of discrepancies among the overall causes, and it is ranked 7th by clients, 2nd by consultants, and 14th by contractors. "Contractor lacks in skilled manpower" is ranked as the 6th important factor of discrepancies among the overall causes, and it is ranked 14th by clients, 4 th by consultants, and 12th by contractors. These six most important causes, based on the overall ranking, are in the design and construction phases. These six causes are the key to improving the design-construction interface by minimising and controlling discrepancies. Recommendations for improvement are summarised as follows:

1. Data required by the design team needs to be provided at the initial stage to enable designers to prepare the design drawings and specifications according to established criteria that are unlikely to change drastically;

2. The designer and consultant need to check that all drawings and specifications used for construction are carefully inspected for on-site construction activities. Managing design changes can help the stakeholders achieve optimum satisfaction on a project. A vigilant role played by the approving authorities ensures that discrepancies are minimised;

3. All the stakeholders, especially the owner, need to pay careful attention to the availability of funds for the project to manage risks that arise during execution;

4. Approving authorities need to make sure that all structures are built according to the approved building plans;

5. Designers need to be given sufficient time to prepare drawings and specifications according to updated building codes. They need to be paid a fee that is commensurate with their efforts;

6. Contractors need to make sure that they are working with skilled manpower and maintaining a high quality of workmanship.

The nationality of participants, the appointment of a designer as consultant, and the appointment of a contractor as the designer are some of the least important causes of discrepancies. Categories of discrepancies are also ranked, and results indicate "design phase" at number 1; "construction phase" at number 2; "tendering phase" at number 3; and "overall phase" at number 4. Clients, consultants, and contractors agree on the need to minimise and control discrepancies in building construction. Useful findings related to the causes of discrepancies in the construction industry are documented. Similar studies can be undertaken elsewhere to investigate how regional and cultural factors influence the findings of this research. Further research is required to determine strategies and suggest solutions to eliminate discrepancies between design and construction on construction projects. 


\section{ACKNOWLEDGEMENTS}

We acknowledge the employees of various clients, consultants, and contractor companies for their valuable input enabling us to complete this research. The authors would like to thank the three anonymous referees for their important suggestions, which have led to the improvement of the paper.

\section{REFERENCES}

Alarcón, L.F. and Mardones, D.A. (1998). Improving the design-construction interface. 6th Annual Conference of the International Group for Lean Construction. Guarujá, Brazil, 13-15 August 1998. Available at: http://www.iglc.net/Papers/ Details/34 [Accessed on 12 February 2015].

Al-Hammad, A.M. (2000). Common interface problems among various construction parties. Journal of Performance of Constructed Facilities, 14(2): 71-74. https:// doi.org/10.1061/(ASCE)0887-3828(2000) 14:2(71)

Alnuaimi, A.S., Taha, R.A., Al-Mohsin, M. and Al-Harthi, A.S. (2010). Causes, effects and remedies of change orders on public construction projects in Oman. Journal of Construction Engineering and Management, 136(5): 615-622. https://doi.org/10.1061/(ASCE)CO.1943-7862.0000154

Andi and Minato, T. (2003). Design documents quality in the Japanese construction industry: Factors influencing and impacts on construction process. International Journal of Project Management, 21 (7): 537-546. https://doi. org/10.1016/S0263-7863(02)00083-2

Arain, F.M. and Pheng, L.S. (2005). How design consultants perceive potential causes of variation orders for institutional buildings in Singapore. Architectural Engineering and Design Management, 1 (3): 181-196. https://doi.org/10.1080 $/ 17452007.2005 .9684592$

Arain, F.M., Pheng, L.S. and Assaf, S.A. (2006). Contractors' views of the potential causes of inconsistencies between design and construction in Saudi Arabia. Journal of Performance of Constructed Facilities, 20(1): 74-83. https://doi. org/10.1061/(ASCE)0887-3828(2006)20:1(74)

Assaf, S.A. and Al-Hammad, A.M. (1988). The effect of economic changes on construction cost. Transactions of the American Association of Cost Engineers. Morgantown, West Virginia: American Association of Cost Engineers, 63-67. Available at: http://search.proquest.com/openview/d6e91366a767cd38 $9143 e 5 \mathrm{db8090a7al/1}$ ?pq-origsite=gscholar\&cbl=27161 [Accessed on 12 February 2015].

Assaf, S.A., Al-Hammad, A.M. and Al-Shihah, M. (1996). Effects of faulty design and construction on building maintenance. Journal of Performance of Constructed Facilities, 10(4): 171-174. https://doi.org/10.1061/(ASCE)08873828(1996) 10:4(171)

Chan, D.W.M. and Kumaraswamy, M.M. (1997). A comparative study of causes of time overruns in Hong Kong construction projects. International Journal of Project Management, 15(1): 55-63. https://doi.org/10.1016/S02637863(96)00039-7

Clough, R.H., Sears, G.A. and Sears, S.K. (2015). Construction contracting: A practical guide to company management, 8th Ed. New York: John Wiley \& Sons Inc. 
Grau, D., Back, W.E., and Prince, J.R. (2012). Benefits of on-site design to project performance measures. Journal of Management in Engineering, 28(3): 232242. https://doi.org/10.1061/(ASCE)ME.1943-5479.0000097

Han, S., Lee, S. and Peña-Mora, F. (2012). Identification and quantification of nonvalue-adding effort from errors and changes in design and construction projects. Journal of Construction Engineering and Management, 138(1): 98109. https://doi.org/10.1061/(ASCE)CO.1943-7862.0000406

Han, S., Love, P. and Peña-Mora, F. (2013). A system dynamics model for assessing the impact of design error in construction projects. Mathematical and Computer Modelling, 57(9-10): 2044-2053. https://doi.org/10.1016/j.mcm.201 1.06.039

Hauck, G. (1983). Hyatt-Regency walkway collapse: Design alternates. Journal of Structural Engineering, 109(5): 1226-1234. https://doi.org/10.1061/(ASCE)07339445(1983) 109:5(1226)

Hinton, P.R., Brownlow, C., McMurray, I. and Cozens, B. (2004). SPSS explained. New York: Routledge.

Kish, L. (1995). Survey sampling, 65th Ed. New York: John Wiley and Sons Inc.

Kong, A.T. and Gray, J.M. (2006). Problems with traditional procurement in the Malaysian construction industry - A survey. In G. Runeson and R. Best (eds.). Proceedings of Australasian Universities Building Educators Association Annual Conference. University of Technology, Sydney, 12-14 July, 1-21.

Lee, S., Peña-Mora, F. and Park, M. (2006a). Reliability and stability buffering approach: Focusing on the issues of errors and changes in concurrent design and construction projects. Journal of Construction Engineering and Management, 132(5): 452-464. https://doi.org/10.1061/(ASCE)07339364(2006) 132:5(452)

Lee, S., Peña-Mora, F. and Park, M. (2006b). Web-enabled system dynamics model for error and change management on concurrent design and construction projects. Journal of Computing in Civil Engineering, 20(4): 290-300. https:// doi.org/10.1061/(ASCE)0887-3801 (2006)20:4(290)

Leech, N.L., Barrett, K.C. and Morgan, G.A. (2005). SPSS for intermediate statistics: Use and interpretation, 2nd Ed. Mahwah, New Jersey: Lawrence Erlbaum Associates Inc.

Lopez, R. and Love, P. (2012). Design error costs in construction projects. Journal of Construction Engineering and Management, 138(5): 585-593. https://doi. org/10.1061/(ASCE)CO.1943-7862.0000454

Lopez, R., Love, P., Edwards, D. and Davis, P. (2010). Design error classification, causation, and prevention in construction engineering. Journal of Performance of Constructed Facilities, 24(4):399-408. https://doi.org/10.1061/ (ASCE)CF.1943-5509.0000116

Love, P., Edwards, D., Irani, Z. and Walker, D. (2009). Project pathogens: The anatomy of omission errors in construction and resource engineering project. IEEE Transactions on Engineering Management, 56(3): 425-435. https://doi. org/10.1109/TEM.2008.927774

Mendelsohn, R. (1997). The constructability review process: A constructor's perspective. Journal of Management in Engineering, 13(3): 17-19. https://doi. org/10.1061/(ASCE)0742-597X(1997)13:3(17)

Ministry of Finance (MOF). (2015). Pakistan Economic Survey 2014-15. Islamabad: Ministry of Finance, Government of Pakistan. Available at: http://www. finance.gov.pk/survey_1415.html [Accessed on 9 November 2015]. 
Mohamad, M.I., Nekooie, M.A. and Al-Harthy, A.B.S. (2012). Design changes in residential reinforced concrete buildings: The causes, sources, impacts and preventive measures. Journal of Construction in Developing Countries, 17(2): 23-44.

Mohammed, N., Che Ani, A.I., Rakmat, R.A.O.K. and Yusof, M.A. (2010). Investigation on the causes of variation orders in the construction of building project - $A$ study in the state of Selangor, Malaysia. Journal of Building Performance, 1 (1): 73-82.

Okpala, D.C., and Aniekwu, A.N. (1988). Causes of high costs of construction in Nigeria. Journal Construction Engineering and Management, 114(2): 233244. https://doi.org/10.1061/(ASCE)0733-9364(1988)114:2(233)

Oyewobi, L.O., Ibironke, O.T., Ganiyu, B.O. and Ola-Awo, A.W. (2011). Evaluating rework cost - A study of selected building projects in Niger State, Nigeria. Journal of Geography and Regional Planning, 4(3): 147-151.

Pakistan Engineering Council (PEC). (2014). Contractors/Firms. Available at: http:// www.pec.org.pk/ [Accessed on 8 January 2014].

Sun, M. and Meng, X. (2009). Taxonomy for change causes and effects in construction projects. International Journal of Project Management, 27(6): 560-572. https://doi.org/10.1016/j.ijproman.2008.10.005

Tenah, K.A. (2001). Project delivery systems for construction: An overview. Cost Engineering, 43(1): 30-36.

Thomas, H.R., Horman, M.J., De Souza, U.E.L. and Zavřski, I. (2002). Reducing variability to improve performance as a lean construction principle. Journal of Construction Engineering and Management, 128(2): 144-154. https://doi. org/10.1061/(ASCE)0733-9364(2002)128:2(144)

Tribelsky, E. and Sacks, R. (2010). Measuring information flow in the detailed design of construction projects. Research in Engineering Design, 21 (3): 189-206. https://doi.org/10.1007/s00163-009-0084-3

Wang, T., Tang, W., Qi, D., Shen, W. and Huang, M. (2016). Enhancing design management by partnering in delivery of international EPC projects: Evidence from Chinese construction companies. Journal of Construction Engineering and Management, 142(4). https://doi.org/10.1061/(ASCE) CO.1943-7862.0001082

Wang, Y. (2000). Coordination issues in Chinese large building projects. Journal of Management in Engineering, 16(6): 54-61. https://doi.org/10.1061/ (ASCE)0742-597X(2000) 16:6(54)

Wantanakorn, D., Mawdesley, M. and Askew, W. (1999). Management errors in construction. Engineering, Construction and Architectural Management, 6(2): 112-120. https://doi.org/10.1108/eb021104 